\title{
NADH Dehydrogenase Activity and Expression of mRNA of Complex I (ND1, 51kDa, and 75kDa) in Heart Mitochondria of klotho Mouse
}

\author{
By \\ Iwao SATO, Mami MIYADO and Masataka SUNOHARA \\ Department of Anatomy, Nippon Dental University School of Dentistry, Fujimi 1-9-20, Chiyoda-ku, Tokyo 102-8159, \\ Japan
}

- Received for Publication, June 8, 2005 -

Key Words: Mitochondria, Aging, Respiratory chain, Heart muscle

\begin{abstract}
Summary: Mitochondrial enzyme activities and ultrastructure of mitochondria prepared from klotho mutant mice were compared with those in wild-type mice. We also measured the levels of expression of ND1, 51kDa, and 75kDa mRNA associated with the genes encoding NADH dehydrogenase and complex I and that of alpha cardiac myosin heavy chain mRNA in both groups. Mitochondrial NADH oxidoreductase activity was higher in klotho mutant mice during aging than that in wild-type mice. The area of mitochondria per unit area $\left(300 \mu \mathrm{m}^{2}\right)$ of cell was almost constant from 4 to 7 weeks of age in both groups. A few large mitochondria were scattered between numerous small mitochondria with compact cristae and myofibrils in klotho mice from 5 weeks of age. The levels of ND1 and 75kDa mRNA were slightly high from 7 weeks of age in klotho mutant mice, whereas they were almost constant in wild-type mice, in spite of reduced expression of alpha cardiac myosin heavy chain mRNA. Our results indicate that klotho protein indirectly plays a role in diminished functional adaptability of enzymes in aged heart muscle, and is required for hypertrophy of cardiac mitochondria.
\end{abstract}

Mice homozygous for the klotho mutation $(\mathrm{kl} /$ $k l)$ are developmentally normal until 3 weeks after birth, but then become inactive and die prematurely at 8 to 9 weeks. The klotho mutation is associated with typical age-related phenotypic characteristics, such as a short lifespan, arteriosclerosis, cardiac dysfunction, ectopic calcification, infertility, atrophy of the thymus, and impaired B cell differentiation $^{13,16,20-22,25-30)}$. The klotho gene is also generally expressed in tissues associated with calcium homeostasis, such as the kidney, brain, parathyroid gland, lung, and heart ${ }^{19)}$.

The respiratory complex is a chain of respiratory enzymes related to NADH dehydrogenase and is encoded by both nuclear and mitochondrial genomes. Our previous study revealed differences in the expression of ND1 and $51 \mathrm{kDa}$ mRNA in postnatal rat tongue muscle ${ }^{8)}$. Increased activity of NADH dehydrogenase is also reportedly associated with structural changes in cristae of mitochondria during development of rat masticatory muscle ${ }^{23)}$.
The number of mitochondria per cytoplasm of mouse decreased while organelle volume remained constant ${ }^{10)}$. In contrast, the volume fraction and size of mitochondria decrease, in contrast to an increase of mitochondrial numerical density, in rat heart during aging ${ }^{7)}$. Aging-related ultrastructural changes have been found in the heart, such as lipid droplets, lipofuchsin granules, and myelin figures ${ }^{7)}$. Large mitochondria are also reported to appear in rat heart under immobilization stress ${ }^{3}$. Age-dependent changes in mitochondrial structure reflect reduced enzyme activity in heart mus$\mathrm{cle}^{6)}$. However, glucose tolerance, insulin sensitivity and phosphoenolpyruvate carboxykinase (PEPCK) activity in klotho mice are higher than those in wild-type mice and the former have less energy expenditure ${ }^{17)}$. The activities of enzymes involved in the mitochondrial electron transport complexes differ in various tissues during aging ${ }^{14)}$. Therefore, it is necessary to examine and compare the activity and levels of respiratory enzymes in klotho mice 
and wild-type mice in terms of the expression of $\mathrm{ND} 1,51 \mathrm{kDa}$, and $75 \mathrm{kDa}$ mRNA associated with the genes encoding NADH dehydrogenase and complex I, in relation to structural changes in the mitochondria of heart muscle, in order to clarify the biological role of klotho protein.

\section{Materials and Methods}

\section{Transmission electron microscopy}

All protocols conformed to the guidelines for the care and used on laboratory animals of Nippon Dental University. The male klotho mutant $(k l / k l)$ mice and wild-type mice (CLEA JAPAN, INC., Tokyo, Japan; each 4 from 4, 5, 6, 7 weeks olds) were fed a solid pellet diet (hard diet, MF, Oriental Yeast Inc., Tokyo, Japan). Mice were deeply anesthetized with ether and killed by cervical dislocation. Small blocks of cardiac chamber of heart muscle from two groups (klotho mutant mice and wild-type mice) were fixed in $2 \%$ glutaraldehydecacodylate buffer ( $\mathrm{pH} 7.2)$ for $2 \mathrm{hr}$ at $4^{\circ} \mathrm{C}$, and postfixed in $1 \%$ osmic acid for $1 \mathrm{hr}$ at $4{ }^{\circ} \mathrm{C}$. After washing with cacodylate buffer $(\mathrm{pH}$ 7.2), they were dehydrated in absolute ethyl alcohol, and then embedded in Epon 812. Cross and longitudinal thin sections of myofibrils for transmission electron microscopy (TEM) were prepared with an ultramicrotome (Ultracut, Reichert-Jung, Vienna, Austria) and stained with uranyl acetate and lead citrate. A Hitachi H-700 transmission electron microscope operating at $80 \mathrm{kV}$ was used for observations. Fifty mitochondria from ten photographs (magnification $\times 10,000$ ) were selected randomly from each section. The cross-sectional areas of mitochondria per unit area $\left(300 \mu \mathrm{m}^{2}\right)$ of cell were measured arbitrarily from several locations using a photo analyzer (Image Gause software, Fuji Film. Tokyo, Japan) linked to a personal computer (EVO 320 , CompaQ, Tokyo, Japan). A total of $50 \mathrm{mi}-$ tochondria in each field were measured.

\section{Isolation of mitochondria}

Mitochondria were isolated by the method of Hogeboom (1955) with slight modifications ${ }^{11}$. The preparation of mitochondria was carried out at $4^{\circ} \mathrm{C}$. The samples were stored at $-80^{\circ} \mathrm{C}$ for later use.

\section{Enzyme assays}

Mouse heart muscle and liver mitochondria ( $0.1 \mathrm{~g}$ of protein) were used for each assay. NADH$\mathrm{O}_{2}$ oxidoreductase activities were measured polarographically using a Clark-type oxygen electrode (Yellow Spring Ltd., Ohio). The assay of oxidase activity with $50 \mathrm{mM}$ Tris- $\mathrm{HCl}(\mathrm{pH} 7.5)$ was performed at $25^{\circ} \mathrm{C}$ in a closed $2 \mathrm{ml}$ reaction chamber equipped with a magnetic stirrer, and rate of oxygen uptake was monitored. Each reaction was initiated by the addition of substrate NADH $(50 \mathrm{mM})$. Protein concentration was determined by the method of Lowry et al. (1951) ${ }^{15)}$, with bovine serum albumin as a standard.

\section{Analysis of $m R N A$ using RT-PCR \\ Isolation of total RNA}

Immediately following the sacrifice of two groups (klotho mutant $(\mathrm{kl} / \mathrm{kl})$ and wild-type mice), $30 \mathrm{mg}$ heart muscles were used for RT-PCR methods. Samples were scrapped off and stored at $-80^{\circ} \mathrm{C}$ until ready for use. The heart muscle was thawed, cut into small pieces and total RNA was extracted with RNeasy Mini Kit (QIAGEN) as per manufacturer's protocol. Contaminating DNA was removed using an RNase-free DNase set (QIAGEN) and the total RNA was quantified by means of spectrophotometry. The samples were stored at $-80^{\circ} \mathrm{C}$ until further use.

Preparation of probes using gene primers Using gene primers are shown in Table 1.

Table 1. Oligonucleotide primers used for RT-PCR

\begin{tabular}{|c|c|c|c|c|}
\hline Transcript & & Sequence & Product (bp) & Gene Bank \\
\hline \multirow[t]{2}{*}{ ND1 } & forward & 5'-TACGAGCCGTAGCCCAAACA-3' & 452 & NC_005089 \\
\hline & reverse & 5'-GATCGTAACGGAAGCGTGGA-3' & & \\
\hline \multirow[t]{2}{*}{$51 \mathrm{kD}$} & forward & 5'-GGGCCTACATCTGTGGAGAAGAGA-3' & 425 & NM_133666 \\
\hline & reverse & 5'-CACCAGTGCATCGAAGTCCATTAG-3' & & \\
\hline \multirow[t]{2}{*}{$75 \mathrm{kD}$} & forward & 5'-CAGGACTTGCCAAAGGATTGTTTC-3' & 477 & AK036926 \\
\hline & reverse & 5'-CTCGGTGACAGCTTTGACACACTT-3' & & \\
\hline \multirow[t]{2}{*}{ MHC-1 } & forward & 5'-GAGCTACTGGAAAGCTGGCTTCTG-3' & 490 & M76601 \\
\hline & reverse & 5'-ACTCTGCCCCTTGGTTACATACTC-3' & & \\
\hline \multirow[t]{2}{*}{ GADPH } & forward & 5'-ACCACAGTCCATGCCATCAC-3' & 452 & M17701 \\
\hline & reverse & 5'-CCACCACCCTGTTGCTGTA-3' & & \\
\hline
\end{tabular}




\section{$R T-P C R$}

The DNA oligonucleotide primers were selected from the nucleotide sequences that have been published for each gene (Table 1). $1 \mu \mathrm{g}$ of total RNA was reverse transcribed in a $25 \mu$ l of the reaction mixture at $42^{\circ} \mathrm{C}$ for $30 \mathrm{~min}$. This reaction mixture consisted of $0.4 \mu \mathrm{M}$ oligo $(\mathrm{dT})_{15}$ primer, $1 \mathrm{mM}$ each dNTP, 20 units of RNase inhibitor (TaKaRa), 17.5 units of AMV reverse transcriptase (TaKaRa), $25 \mathrm{mM}$ Tris- $\mathrm{HCl}(\mathrm{pH} 8.3), 50 \mathrm{mM} \mathrm{KCl}, 2 \mathrm{mM}$ of DTT and $10 \mathrm{mM} \mathrm{MgCl}$. For the negative control, a total RNA sample without added reverse transcriptase was tested for DNA contaminants. For PCR, $1 \mu \mathrm{l}$ of the cDNA mixture was added to $25 \mu \mathrm{l}$ of master mix. This master mix consisted of $400 \mu \mathrm{M}$ each dNTP, $0.4 \mu \mathrm{M}$ each forward primer and reverse primer, 0.5 units of Ampli Taq Gold (Applied Biosystems, Foster, CA). The reactions were performed under different annealing temperature and cycle repetitions: $60^{\circ} \mathrm{C}$ and 40 cycles for GAPDH; $60^{\circ} \mathrm{C}$ and 36 cycles for $\mathrm{ND} 1 ; 60^{\circ} \mathrm{C}$ and 40 cycles for $51 \mathrm{kDa} ; 60^{\circ} \mathrm{C}$ and 40 cycles for $75 \mathrm{kDa} ; 60^{\circ} \mathrm{C}$ and 40 cycles for alpha cardiac myosin heavy chain mRNA (MHC-I). An aliquot of each PCR product was separated on a $1.5 \%$ agarose gel and stained with ethidium bromide. The stained gels were photographed under ultraviolet illuminator using Polaroid film. The intensity of the bands was quantified using Image Gause software (Fuji Film, Tokyo, Japan).

\section{Statistical analysis}

Data are presented as mean \pm SEM. Statistical analysis was performed by employing commercially available software (Microsoft ${ }^{\circledR}$ office Excel 2003). Differences between hearts muscle in klotho mutant $(k l / k l)$ and wild-type mice were tested using the t-test. Correlations between groups of values were evaluated calculating the best fit, based on least-squares regression analysis. The regression lines were then represented and the coefficient of correlation (R) was indicated. For the statistical analyses, significance was accepted at $\mathrm{p}<0.05(* 1$, show in figures) and $\mathrm{p}<0.01$ (*2, show in figures), and $\mathrm{p}<0.001$ (*3, show in figures).

\section{Results}

The body weight of klotho mutant mice was almost constant from 4 to 7 weeks, and was lower than that of wild-type mice (Fig. 1). We determined the activities of one respiratory chain enzyme contained in the mitochondrial inner membrane (Fig. 2). In klotho mutant mice, $\mathrm{NADH}-\mathrm{O}_{2}$ oxidoreductase activity of the mitochondrial respiratory

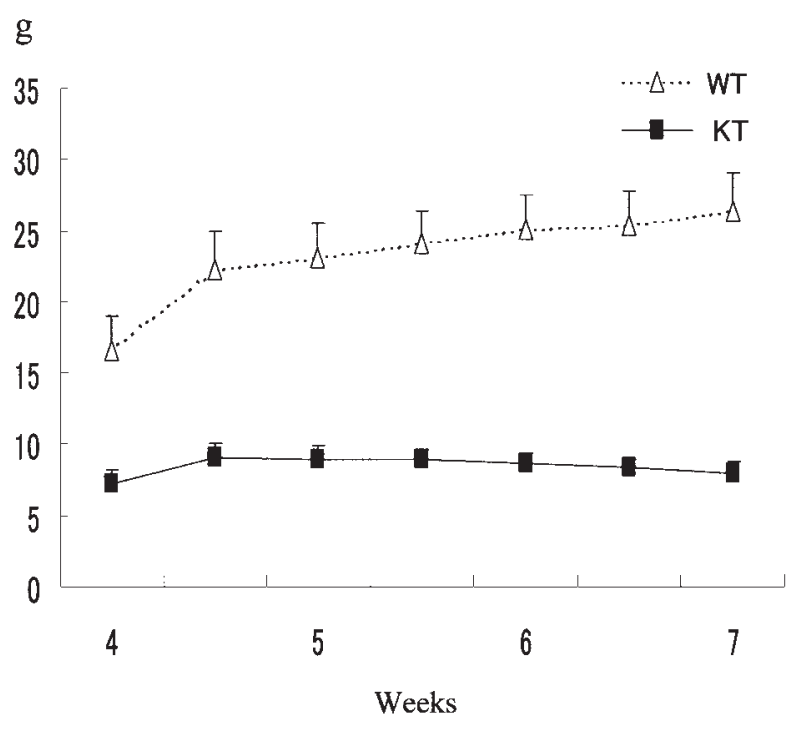

Fig. 1. Changes of body weigh changes of the klotho mutant mice (KT) and wild-type mice (WT) during development.

chain in heart muscle increased rapidly from 6 weeks of age (Fig. 2a), whereas the levels of other mitochondrial proteins decreased from the same time point (total protein/mg: 5 weeks, $147.5 \mathrm{mg}$ / $\mathrm{ml}$ per $1 \mathrm{~g} ; 6$ weeks, $19.0 \mathrm{mg} / \mathrm{ml}$ per $1 \mathrm{~g} ; 7$ weeks, $6.1 \mathrm{mg} / \mathrm{ml}$ per $1 \mathrm{~g}$ ), and were lower than those of wild-type mice (total protein $/ \mathrm{mg}$ : 5 weeks, $205.3 \mathrm{mg} / \mathrm{ml}$ per $1 \mathrm{~g} ; 6$ weeks, $110.2 \mathrm{mg} / \mathrm{ml}$ per $1 \mathrm{~g}$; 7 weeks, $47.1 \mathrm{mg} / \mathrm{ml}$ per $1 \mathrm{~g}$ ). NADH-O 2 oxidoreductase activity of the mitochondrial respiratory chain in the liver decreased gradually from 5 weeks onwards in klotho mutant mice (total protein/mg: 5 weeks, $15.6 \mathrm{mg} / \mathrm{ml}$ per $1 \mathrm{~g} ; 6$ weeks, $105.3 \mathrm{mg} / \mathrm{ml}$ per $1 \mathrm{~g} ; 7$ weeks, $99.6 \mathrm{mg} / \mathrm{ml}$ per $1 \mathrm{~g}$ ), and was drastically lower than that in 6- and 7-week-old wild-type mice (total protein/mg: 5 weeks, $16.4 \mathrm{mg} / \mathrm{ml}$ per $1 \mathrm{~g}$; 6 weeks, $717.3 \mathrm{mg} / \mathrm{ml}$ per $1 \mathrm{~g} ; 7$ weeks, $448.1 \mathrm{mg} /$ $\mathrm{ml}$ per $1 \mathrm{~g}$ ) (Fig. 2b).

The size of mitochondrion heart muscle was almost constant throughout the study period (Fig. $3)$. There were no differences in the size of mitochondrion between klotho mutants and wild-type mice. We also examined differences in other mitochondrial features. In the mutants, loss of crista membranes occurred mainly in large mitochondria, which gradually increased in number and showed a scattered distribution in myocardial cells (Fig. 4).

We also measured the levels of expression of ND1, 51kDa mRNA, and $75 \mathrm{kDa}$ associated with the genes encoding NADH dehydrogenase and complex I (Fig. 5a). In klotho mutant mice, the expression of ND1 and $75 \mathrm{kDa}$ mRNA was constant 

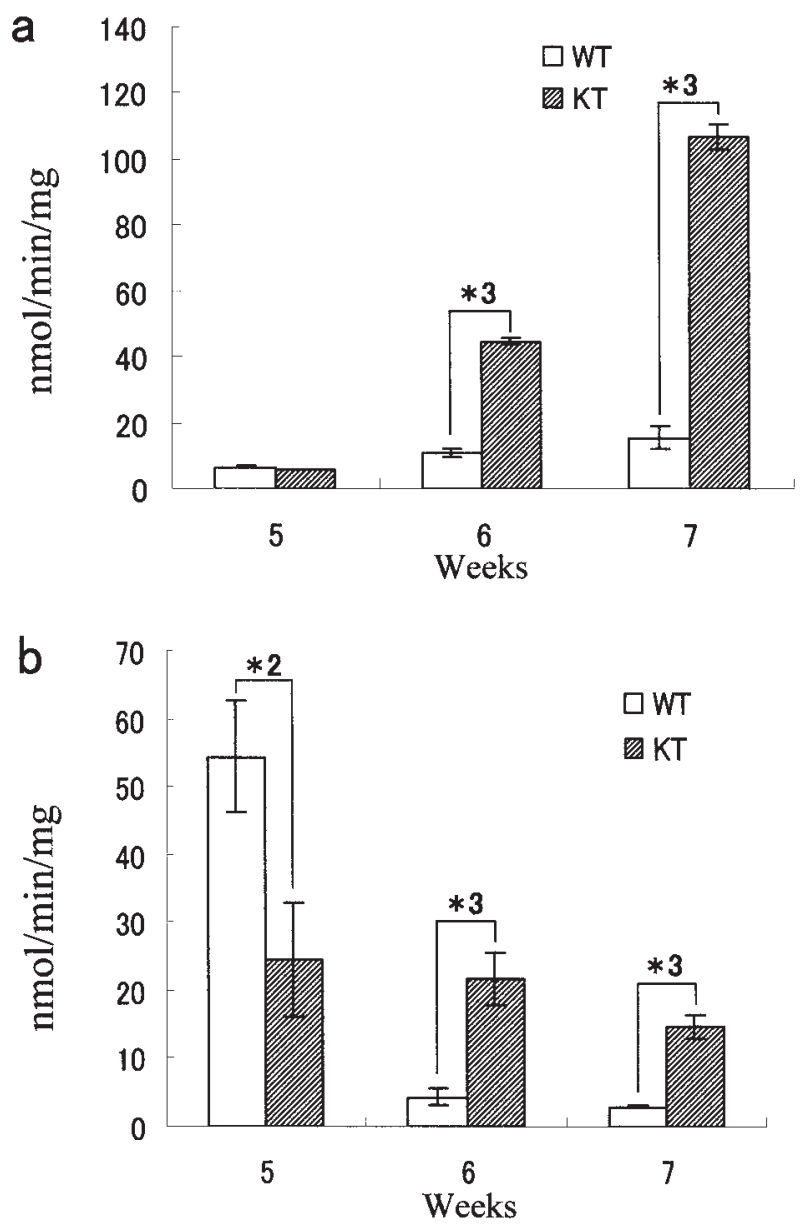

Fig. 2. Developmental changes in respiratory chain enzyme activity (NADH- $\mathrm{O}_{2}$ oxidoreductase) of isolated mitochondria of heart muscle (a) and liver (b) from the klotho mutant mice (KT) and wild-type mice (WT). Values are means and standard deviation. $\mathrm{p}<0.01(* 2)$, $\mathrm{p}<0.001\left(*^{3}\right)$

from 5 to 6 weeks of age, and slightly higher at 7 weeks of age than that in wild-type mice, which was almost constant for 4 weeks (Figs. 5b, d). The expression level of $51 \mathrm{kDa}$ mRNA was almost constant in both klotho mutant and wild-type mice (Fig. 5c). In contrast, the expression level of alpha cardiac myosin heavy chain mRNA increased gradually from 5 weeks of age in both groups, and was lower at 7 weeks of age in klotho mutant mice than in wild-type mice (Figs. 6a, b).



Fig. 3. Developmental changes in measurement (cross-sectional area of mitochondria) of heart mitochondria of the klotho mutant mice (KT) and wild-type mice (WT). Values are means and standard deviation. $\mathrm{p}<0.001\left(*^{3}\right)$

\section{Discussion}

It has been reported that there is a decline in total aerobic NADH oxidation (coenzyme Q reductase and cytochrome oxidase activities), but no change in ubiquinol-cytochrome $c$ reductase activity in hearts of rats aged 24 months ${ }^{10)}$. It is expected that in the type of aging shown by klotho mutant mice, the energy-producing system runs at a low basic level because of atrophy of the pancreas. The klotho mutant mouse possesses less stored energy in the form of glycogen in the liver ${ }^{17}$. Our present study showed that the enzyme activity of the respiratory chain in heart mitochondria of klotho mutant mice increased rapidly during aging, and that the levels were higher than in wild-type mice at each stage. In contrast, respiratory chain enzyme activity in liver mitochondria of klotho mutant mice decreased during aging, although the level of activity was higher than that of wild-type mice from 4 to 7 weeks of age. In rat heart mitochondria, NADH cytochrome $c$ reductase and cytochrome oxidase activities are known to increase up to 12 months of age, and then decrease at $18-26$ months $^{5)}$. However, in the present study, total mitochondrial proteins isolated from heart muscle of klotho mutant mice were decreased from 6 weeks of age, and the levels of all of them were lower than those of wild-type mice throughout the

Fig. 4. Electron micrographs of heart mitochondria (mt) in the klotho mutant mice (b, d, f, h) and wild-type mice (a, c, e, g). A few large mitochondria with disappeared cristae (arrows) around the membranes and the swelling and vacuolation of mitochondria partial found in cells. a, b) 4 weeks of age, c, d) 5 weeks of age , e, f) 6 weeks of age, g, h) 7 weeks of age, (a-c, e, g, h: bar $=1 \mu \mathrm{m} ; \mathrm{d}, \mathrm{f}:$ bar $=400 \mathrm{~nm})$. 


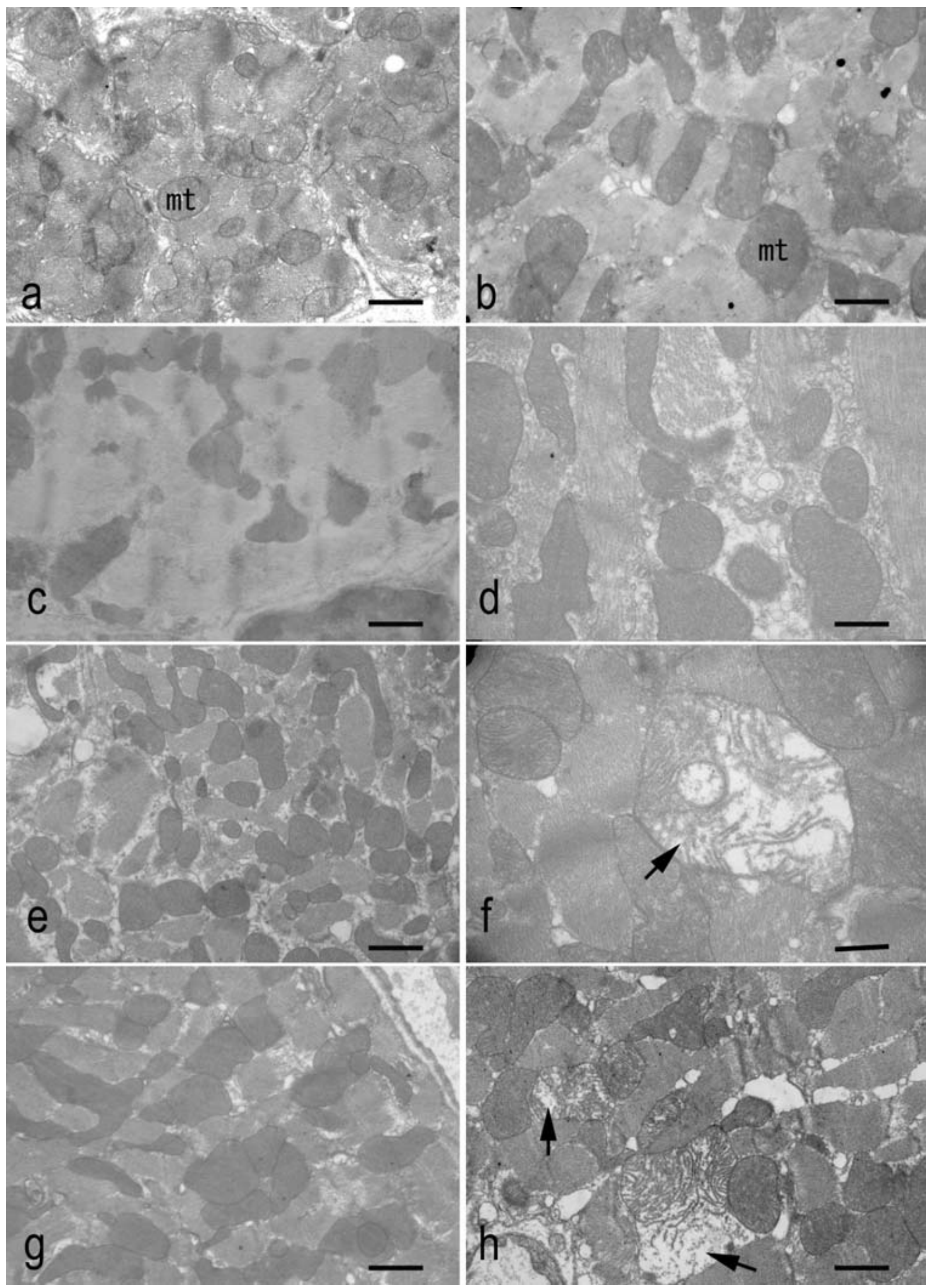



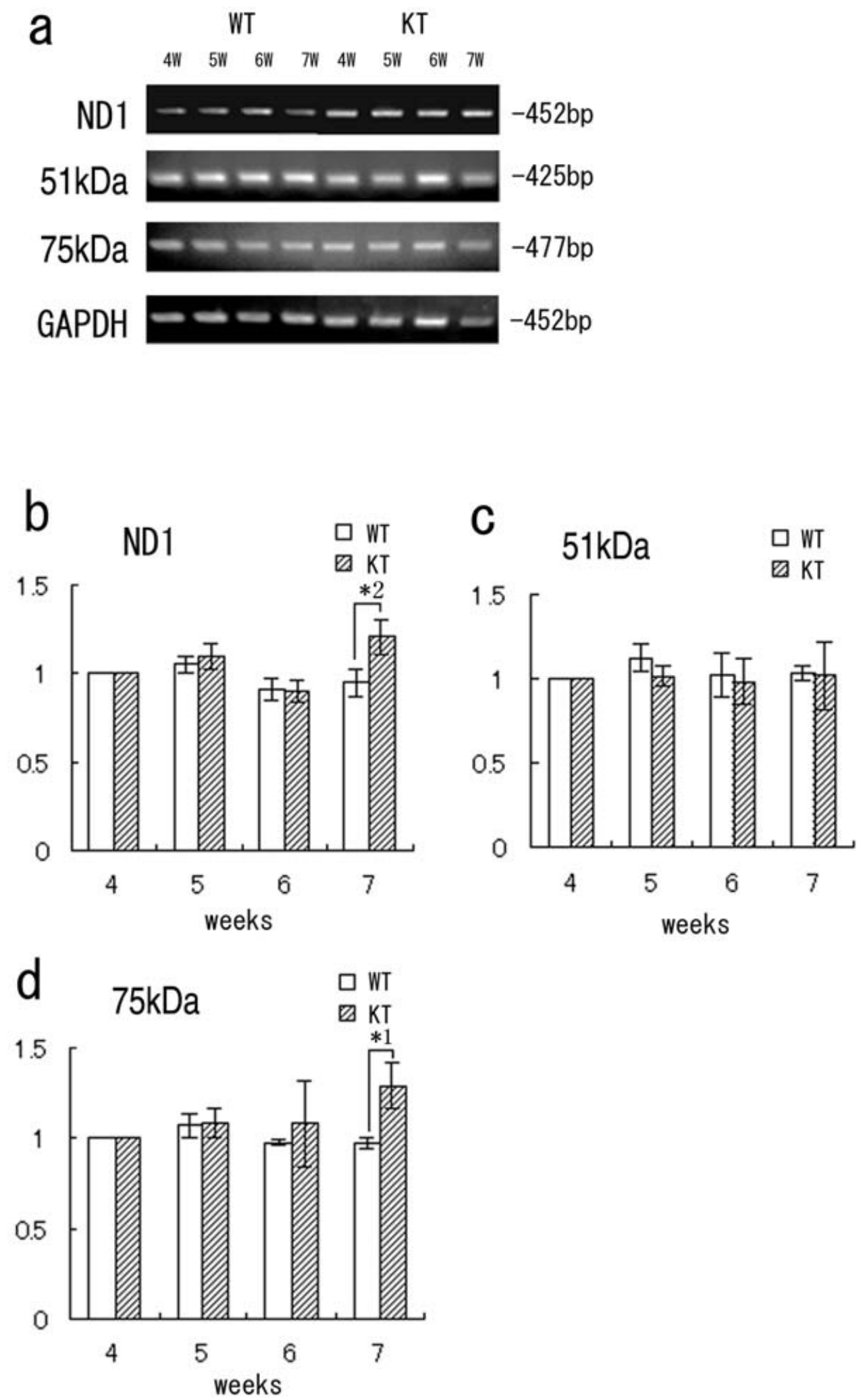

Fig. 5. Semi-quantification of complex I (ND1, 51kDa, $75 \mathrm{kDa})$ and $(\mathrm{GAPDH}) \mathrm{mRNA}$ by RT-PCR in heart mitochondria of the klotho mutant mice (KT) and wild-type mice (WT). Gel-electrophoretic pattern of ND1, 51kDa, 75kDa and GAPDH (a) and relative changes in ND1 (b), $51 \mathrm{kDa}(\mathrm{c})$, and $75 \mathrm{kDa}$ (d) mRNA of heart mitochondria on 4-,5-,6-, and 7 weeks of ages. Values are means and standard deviation. $\mathrm{p}<0.05(* 1), \mathrm{p}<0.01(* 2)$ 

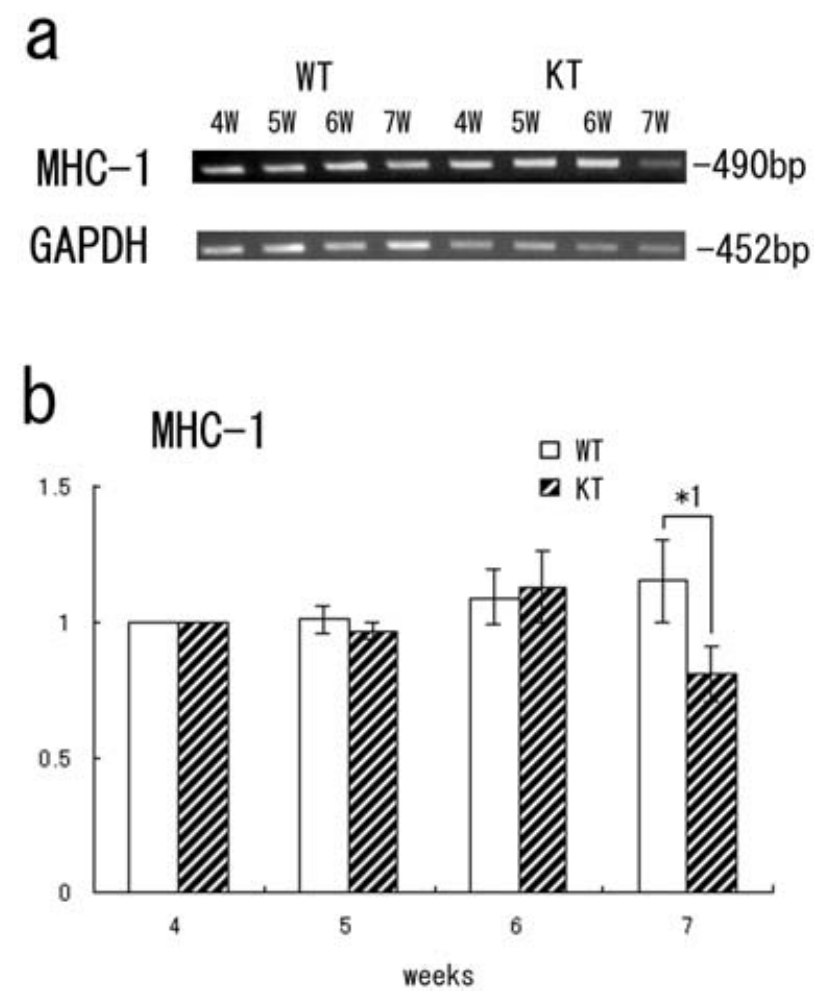

Fig. 6. Semi-quantification of cardiac myosin heavy chain (MHC-1) and GAPDH mRNA by RT-PCR in heart mitochondria of the klotho mutant mice (KT) and wild-type mice (WT). Gel-electrophoretic pattern of MHC-1 and GAPDH (a) and relative changes in MHC-1 (b) mRNA of heart mitochondria on 4-,5-,6-, and 7 weeks of ages.

study period. Our findings suggested that in klotho mutant mice the potential for mitochondrial enzyme activity in the heart is high during aging, in spite of the reduced amount of mitochondrial protein. Our previous study showed that muscle mitochondrial enzyme activity was higher during hibernation than during active life ${ }^{24)}$. Similar results have been reported for some species of fish ${ }^{1,18)}$. Activities of some individual complexes are known to be decreased in old animals, but no common pattern can be discerned among various tissues ${ }^{14)}$. Stored glycogen is slowly utilized to produce energy in response to aging or stress, and in klotho mutant mice compared with wild-type mice, the respiratory chain in heart mitochondria functions actively, in contrast to liver mitochondria.

$51 \mathrm{kDa}$ and $75 \mathrm{kDa}$ mRNA from the nuclear genome and ND1 mRNA from the mitochondrial genome encode key protein subunits for the formation of $\mathrm{NADH}$ dehydrogenase ${ }^{2,8}$. Our study showed that the levels of ND1 and $75 \mathrm{kDa}$ mRNA were slightly higher in klotho mutant mice from 7 weeks of age, whereas they remained almost constant in wild-type mice. These findings suggest that the high level of enzyme activity in klotho mutant mice at 3-6 weeks of age is not due to enzyme regulation. As heart muscle is unable to receive sufficient glucose from the blood ${ }^{17)}$, then the high enzyme activity in klotho mutants might serve to maintain normal circulatory conditions, except in 7week-old mice. Hypertension can cause a reduction in the level of mRNA for cardiac sarcoplasmic reticular calcium-activated ATPase ${ }^{4)}$. However, the level of alpha-skeletal actin mRNA is lower in aged skeletal muscle and uterus, but higher in aged myocardium $^{12}$. Therefore, the high expression of ND1 and $75 \mathrm{kDa}$ mRNA in the mitochondria at 7 weeks of age in klotho mutant mice is possibly due to gene derepression caused by hypertrophy of cardiac mitochondria and myocytes.

In this study, we investigated the ultrastructure of the mitochondria prepared from klotho mutant and wild-type mice. TEM indicated that large mitochondria showing loss of cristae were present in the klotho mutant mice from 5 to 7 weeks of age. Our results also indicated reduced levels of alpha cardiac myosin heavy chain mRNA from 7 weeks of age. Buttrick et al. (1991) reported a 46\% reduction in alpha myosin heavy chain mRNA in 24-monthold rats in comparison with 4-month-old rats ${ }^{4)}$. Frenzel and Feiman (1984) also observed a reduction in the transverse diameter of ventricular myofibrils in aged (2-year-old) rats ${ }^{7}$. Therefore the functional adaptability of heart myofibrils is diminished in aged rats in comparison with klotho mutant mice.

\section{Acknowledgments}

We thank Ms Naoko Hasegawa for polarographic assay and expression mRNA assistance.

\section{References}

1) Battersby BJ and Moyes CD. Influence of acclimation temperatire on mitochondrial DNA, RNA, and enzymes in skeletal muscle. Am J Physiol 1998; 275:R905-R912.

2) Belogrudov GI and Hatefi Y. Intersubunit interactions in the bovine mitochondrial complex I as revealed by ligand blotting. Biochem Biophys Res Commun 1996; 227:135139.

3) Bozner A, Balaz V, Dostal J and Szigetiova A. Electron microscopy morphometric analysis of the effect of immobilization stress on the structure of the myocardium in rats belonging to 2 age groups. Cesk Patol 1984; 20:146-150.

4) Buttrick P, Malhotra A, Factor S, Greenen D, Leinwand L and Scheuer J. Effect of aging and hypertension on myosin 
biochemistry and gene expression in the rat heart. Circ Res 1991; 68:645-652.

5) Castelluccio C, Baracca A, Fato R, Pallotti F, Maranesi M, Barzanti V, Gorini A, Villa RF, Parenti Castelli G, Marchetti M, et al. Mitochondrial activities of rat heart during ageing. Mech Ageing 1994; 76:73-88.

6) Coleman R, Weiss A, Finkelbrand S and Silbermann M. Age and exercise-related changes in myocardial mitochondria in mice. Acta Histochem 1988; 83:81-90.

7) Frenzel $\mathrm{H}$ and Feimann J. Age-dependent structural changes in the myocardium of rats. A quantitative lightand electron-microscopic study on the right and left chamber wall. Mech Ageing Dev 1984; 27:29-41.

8) Fujita $\mathrm{T}$ and Sato I. NADH-O $\mathrm{O}_{2}$ oxidoreductase activity and mRNA expression of complex I (51kDa, ND1) in postnatal intrinsic muscle of rat tongue. J Anat 2003; 202:205-212.

9) Genova ML, Castelluccio C, Fato R, Parenti Castelli G, Merlo Pich M, Formiggini G, Bovina C, Marchetti M and Lenaz G. Major changes in complex I activity in mitochondria from aged rats may not be detected by direct assay of NADH: coenzyme Q reductase. Biochem J 1995; 311:105-109.

10) Herbener GH. A morphometric study of age-dependent changes in mitochondrial population of mouse liver and heart. J Gerontol 1976; 31:8-12.

11) Hogeboom HG. Fractionation of cell components of animal tissues. In: Colowick SP, Kaplan NO (editors). Methods in Enzymology: vol. 1 Preparation and assay of enzymes. pp. 16-19, Academic Press, New York, 1955.

12) Jaiswal YK and Kanungo MS. Expression of actin and myosin heavy chain genes in skeletal, cardiac and uterine muscles of young and old rats. Biochem Biophys Res Commun 1990; 168:71-77.

13) Kuro-o M, Matsumura Y, Aizawa H, Kawaguchi H, Suga T, Utsugi T, Ohyama Y, Kurabayashi M, Kaname T, et al. Mutation of the mouse klotho gene leads to a syndrome resembling ageing. Nature 1997; 390:45-51.

14) Kwong LK and Sohal RS. Age-related changes in activities of mitochondrial electron transport complexes in various tissues of the mouse. Arch Biochem Biophys 2000; 373:1622.

15) Lowry OH, Rosebrough NJ, Farr A and Randall RJ. Protein measurement with the Folin phenol reagent. J Biol Chem 1951; 193:265-275.

16) Manabe N, Kawaguchi H, Chikuda H, Miyaura C, Inada M, Nagai R, Nabeshima Y, Nakamura K, Sinclair AM, Scheuermann RH and Kuro-o M. Connection between B lymphocyte and osteoclast differentiation pathways. J Immunol 2001; 167:2625-2631.

17) Mori K, Yahata K, Mukoyama M, Suganami $T$, Makino $H$, Nagae T, Masuzaki H, Ogawa Y, Sugawara A, Nabeshima $\mathrm{Y}$ and Nakao K. Disruption of klotho gene causes an abnormal energy homeostasis in mice. Biochem Biophys Res Commun 2000; 278:665-670.

18) Moyes CD, Buck LT and Hochachka PW. Temperature effects on $\mathrm{pH}$ of mitochondria isolated from carp red muscle. Am J Physiol 1988; 254:R611-R615.

19) Nabeshima Y. Klotho: a fundamental regulator of aging. Ageing Res Rev 2002; 1:627-638.

20) Okada S, Yoshida T, Hong $Z$, Ishii G, Hatano M, Kuro-O M, Nabeshima Y, Nabeshima Y and Tokuhisa T. Impairment of B lymphopoiesis in precocious aging (klotho) mice. Int Immunol 2000; 12:861-871.

21) Saito $Y$, Yamagishi $T$, Nakamura $T$, Ohyama $Y$, Aizawa H, Suga T, Matsumura Y, Masuda H, Kurabayashi M, Kuro-o M, Nabeshima $Y$ and Nagai R. Klotho protein protects against endothelial dysfunction. Biochem Biophys Res Commun 1998; 248:324-329.

22) Saito $Y$, Nakamura $T$, Ohyama $Y$, Suzuki $T$, Iida A, Shiraki-Iida T, Kuro-o M, Nabeshima Y, Kurabayashi M and Nagai R. In vivo klotho gene delivery protects against endothelial dysfunction in multiple risk factor syndrome. Biochem Biophys Res Commun 2000; 276:767-772.

23) Sato I, Konishi K, Kuramochi $T$ and Sato T. Developmental changes in enzyme activities and in structural features of rat masticatory muscle mitochondria. J Dent Res 1998; 77:1926-1930.

24) Sato I, Konishi K, Masataka S and Mikami A. Enzyme activities and morphology of Japanese brown frog (Rana japonica) mitochondria in the tibialis anterior muscle during hibernation and active life. Can J Zool 2001; 79:1316-1321.

25) Utsugi T, Ohno T, Ohyama Y, Uchiyama T, Saito Y, Matsumura Y, Aizawa H, Itoh H, Kurabayashi M, Kawazu S, Tomono S, Oka Y, Suga T, Kuro-o M, Nabeshima Y and Nagai R. Decreased insulin production and increased insulin sensitivity in the klotho mutant mouse, a novel animal model for human aging. Metabolism 2000; 49:1118-1123.

26) Suga $T$, Kurabayashi M, Sando $Y$, Ohyama $Y$, Maeno $T$, Maeno Y, Aizawa H, Matsumura Y, Kuwaki T, Kuro-O M, Nabeshima Y and Nagai R. Disruption of the klotho gene causes pulmonary emphysema in mice. Defect in maintenance of pulmonary integrity during postnatal life. Am J Respir Cell Mol Biol 2000; 22:26-33.

27) Yamashita T, Nifuji A, Furuya K, Nabeshima $Y$ and Noda M. Elongation of the epiphyseal trabecular bone in transgenic mice carrying a klotho gene locus mutation that leads to a syndrome resembling aging. J Endocrinol 1998; 159:18.

28) Yamashita T, Yoshitake H, Tsuji K, Kawaguchi N, Nabeshima $\mathrm{Y}$ and Noda M. Retardation in bone resorption after bone marrow ablation in klotho mutant mice. Endocrinology 2000a; 141:438-445.

29) Yamashita T, Nabeshima $Y$ and Noda M. High-resolution micro-computed tomography analyses of the abnormal trabecular bone structures in klotho gene mutant mice. J Endocrinol 2000b; 164:239-245.

30) Yamashita T, Sekiya I, Kawaguchi N, Kashimada K, Nifuji A, Nabeshima YI and Noda M. Klotho-deficient mice are resistant to bone loss induced by unloading due to sciatic neurectomy. J Endocrinol 2001; 168:347-351. 